\title{
THE IMPORTANCE OF CSR IMPLEMENTATION
}

\author{
Anna Križanová ${ }^{1}$, Lubica Gajanová2
}

\begin{abstract}
The last three decades of the twentieth century and the beginning of the twenty-first century were marked by the expansion of managerial ethics and social responsibility of business. Business ceased to be perceived in terms of profit being the sole interest of management, and ethical aspects were stressed more so in connection with the company's management. Specific managerial ethical initiatives and activities leading from outside and inside the organization constitutes the concept of Corporate Social Responsibility (CSR), which comprises many factors. The aim of this paper is to summarize the positive impact of corporate social responsibility for business activities using secondary data from global surveys and then confirm the importance and benefits of corporate social responsibility for enterprises in the Slovak Republic using primary data.
\end{abstract}

JEL Classification Numbers: M21 DOI: http://dx.doi.org/10.12955/cbup.v4.807

Keywords: corporate social responsibility, benefit, CSR implementation.

\section{Introduction}

Reflections on ethical behavior are increasingly being cited, and in recent times this has transmitted into the plane of business. The last three decades of the twentieth century and the beginning of the twenty-first century were marked by the expansion of managerial ethics and social responsibility of business. Business ceased to be perceived in terms of profit being the sole interest of management, while ethical aspects were stressed more so in connection with a company's management. In professional circles, various recommendations and examples of ethical business practices, directed both inside (to employees) and outside the organization (to the environment and society), have been described (Veber, 2006). Specific managerial ethical initiatives and activities for leading outside and inside the organization constitutes the concept of Corporate Social Responsibility (CSR), which involves various factors.

The current economic conditions of increasing globalization and corrupt practices could be included among the significant catalysts of the CSR application. Under these conditions there is a growing need for a stable environment given the increasing public interest about the transparency of corporate activities (Srpová \& Kunz, 2009). In addition, companies may realize the importance of setting their own behavior rather than accepting a framework of authoritatively oriented regulations that are a response to inappropriate organizational behavior (Putnová \& Seknička, 2007).

The concept of CSR, in professional terms, is a continuous commitment by companies towards behaving ethically and in contributing to economic growth, while striving to improve the quality of life for employees and their families, as well as local communities and society as a whole (Trnková, 2004).

\section{Literature Review}

Numerous academic literature, surveys, research, and studies emphasize the reasons for CSR implementation. Putnová (2004) and Putnová and Seknička (2007) presented three sets of possible reasons for adopting corporate social responsibility. Of these, the first is to avoid government intervention; it is better for companies to set their own framework of behavior than to accept regulation from the outside. The second reason is the need for self-regulation of business in response to growing economic power; large companies through their actions can provide models for smaller firms to emulate. The third reason is the changing public perception of business. Consumers, particularly in Western Europe, are increasingly interested in the background of the manufactured product they intend purchasing and are forever more seeking accessible information before they decide on their purchase or conversely, elect for a consumer boycott.

\footnotetext{
${ }^{1}$ Anna Križanová, Faculty of Operation and Economics of Transport and Communications, University of Žilina, Žilina, Slovakia, anna.krizanova@fpedas.uniza.sk

${ }^{2}$ Lubica Gajanová, Faculty of Operation and Economics of Transport and Communications, University of Žilina, Žilina, Slovakia, lubica.gajanova@fpedas.uniza.sk
} 
Petř́ková, Hofbruckerová, Lešingrová, Klesalová, \& Hercík (2008), Kuldová (2010), Dytrt (2006), and Hohnen (2007) presented other possible reasons for adopting the CSR concept, such as, increased attractiveness to investors and long-term sustainability of the company. Other reasons include profit growth, increase of the company's value, access to capital, greater transparency, and enhanced trust and corporate culture. In terms of production, they include creating new job opportunities, especially for members of the local community; attracting and retaining quality employees; increasing employee loyalty to the leadership and increasing their productivity; and creating an environment that enables employees to develop their full potential. From a marketing perspective, reasons include building a reputation and the resulting strong position in the market; gaining a competitive advantage and greater original brand resolution by the consumer; sales growth and customer loyalty; increasing value of intangible assets, e.g., goodwill, brand value, quality of products and services, and quality of management; direct savings resulting from the quality of products and services; improving ability to attract and build effective and efficient supply chain relationships; increasing efficiency, opportunity for innovation, learning and continuous improvement of the company, building of political capital, decreasing costs of risk management, and direct financial savings associated with environmentally friendly practices (Hlaváček \& Hlaváček, 2008; Moravčíková, Stefanikova, \& Rypakova, 2015; Bachanova, Corejova, \& Rostasova, 2009; Hrašková \& Bartošová, 2014; Majerová \& Križanová, 2015; Štefániková et. al, 2015; Nadányiová \& Kramárová, 2013; Gregova \& Dengova, 2014; Tokarcikova, Bartosova, Kucharcikova, \& Durisova, 2014). Hohnen (2007) added that by applying the principles of CSR, companies could affect responsible consumption, which would lead to sustainable development. It is not only the consumers who, through the preference of some products and consumer boycotts, contribute to sustainable development, but also the responsible behavior of organizations. The companies have the choice as to whether their products will reflect consumers' rights and comply with the principles of sustainable development or not. It is not easy to determine the conditions by which business obtains benefits from the introduction of socially responsible activities and which are necessary to maximize these benefits. Experts agree and point to the same or similar group benefits. Benefits of CSR strategies are usually difficult to measure because, in most cases, they are benefits of intangible nature that are not readily quantifiable (Trnková, 2006).

There are numerous of international studies dealing with CSR that confirm its positive impacts and benefits for business. Research by the Faculty of Economics and Administration at the Masaryk University in 2007 involving 251 companies in the manufacturing and construction industry showed that the most common reasons for adopting CSR was the visibility and image of the company, improved promotion of positive events, and building trustworthy relationships, promoting beneficial and useful services in connection with advertising, and sense of responsibility and promotion of the "right and important things" with reference to moral principles. In summary, the ratio of marketing and ethical reasons for the adoption of CSR among companies is well balanced (Kašparová, 2009).

Another survey of the economic benefits and long-term effects of corporate social responsibility on business was carried out in connection with the implementation of the CSR program of the Republic of Lithuania and the project of the United Nations Development Program "GATES: Social and Environmental Business Innovations". One purpose of the survey was to identify the CSR factors generating economic benefit. In a summary of the results of the CSR economic benefits analysis, Ernst and Young Global Limited (2013) provided the following conclusions:

- Most corporate CSR initiatives assessed in the survey yield benefits, i.e., generate a positive return on investment ( $45 \%$ on average);

- The assessment of the economic return on SCR initiatives for separate CSR areas showed that the highest economic return was generated by initiatives in the area of personnel (133\% on average) and the lowest by environmental initiatives (33\% on average);

- The highest return on CSR activities was identified in the companies where the corporate social responsibility activities were mostly interconnected with the overall strategy and business model of the company; and

- The highest economic return was generated by the CSR initiatives where the implementation was result-oriented, i.e., no surplus activities are carried out without added value. 
The respondents of the abovementioned survey were 142 managers who attended Harvard Business School's CSR executive education program during the previous four years. The respondents were asked about the range, structure, and oversight of their firm's CSR activities. According to the results of this survey, the CSR programs often improve efficiency and effectiveness. Thus, they may, but not always, increase revenue, decrease costs, or both. Examples include sustainability initiatives that reduce resource use, waste, or emissions, which may in turn reduce costs; and investments in employee working conditions, health care, or education that may enhance productivity, retention, and company reputation (Rangan, Chase, \& Sohel, 2015).

Caroll and Shabana (2010) dealt with a variety of reasons for considering CSR in their business case through a review of concepts, research, and practice. They reported potential benefits such as, reducing costs and risks, gaining competitive advantages, developing and maintaining legitimacy and reputational capital, and achieving win-win outcomes through synergistic value creation.

Justifications for cost and risk reduction include the argument that engaging in certain CSR activities will reduce the firm's inefficient capital expenditure and thus reduce exposure to risk. Competitive advantage is understood as a differentiation strategy; in that the focus is on how firms can use CSR practices to set themselves apart from their competitors. In this context, stakeholder demands are viewed as opportunities rather than constraints. Firms strategically manage their resources to meet these demands and exploit the opportunities associated with them for the benefit of the firm. This approach to CSR requires firms to integrate their social responsibility initiatives with their broader business strategies. Companies may also justify their CSR initiatives on the basis of creating, defending, and sustaining their legitimacy and strong reputations. A business is perceived as legitimate when its activities are congruent with the goals and values of the society in which the business operates. In other words, a business is perceived as legitimate when it fulfills its social responsibilities. The argument for creating synergistic value focuses on exploiting opportunities that reconcile differing stakeholder demands. Firms do this by connecting stakeholder interests and creating pluralistic definitions of value for multiple stakeholders, simultaneously. In other words, with a large enough cause, they can unite many potential interest groups (Caroll \& Shabani, 2010).

In this study, we examine the positive impact of CSR implementation in companies of the Slovak republic using a marketing survey to determine the importance and benefits of CSR for such companies.

\section{Data and Methodology}

The marketing survey was carried out during 2015 on a sample of 47 respondents from Slovak companies that had implemented a system of CSR. The survey was conducted to detect the level of exploitation of CSR in Slovak enterprises. One objective was to assess the advantages of using CSR by assessing the following research question: Is there a statistically significant relationship between the competitive position of the Slovak companies and their stage of CSR? To answer the research question we focused on the competitive position of the business representatives (the respondents). The business representatives had to rate questions displayed graphically on a six-point scale from "1" (unviable) to " 6 " (at a dominant competitive position). To detect the stage of CSR we used the scale proposed by Visser (2010). This viewed the evolution of business responsibility in five overlapping economic periods: Ages of Greed, Philanthropy, Marketing, Management, and Responsibility, with each typically manifesting another stage of CSR, namely, Defensive, Charitable, Promotional, Strategic, or Transformative (Visser, 2010).

To confirm or reject the research relational, the survey questions were set based on the hypothesis:

Between the competitive position of the Slovak companies and their stage of CSR there is no statistically significant relationship.

A significance level $\alpha$ was determined at 0.05 and corresponded to $95 \%$ confidence interval. To calculate the test statistic, we used IBM SPSS Statistics software.

\section{Results and Discussion}

The results revealed at a significance level $<0.05$, meaning the null hypothesis was rejected. Hence, the results show a statistically significant relationship between the competitive position of the Slovak 
companies and their stage of CSR. Thus, a higher level of development of social responsibility in Slovak companies will likely provide the companies with a better competitive position in the market.

Figure 1: Result of test statistics

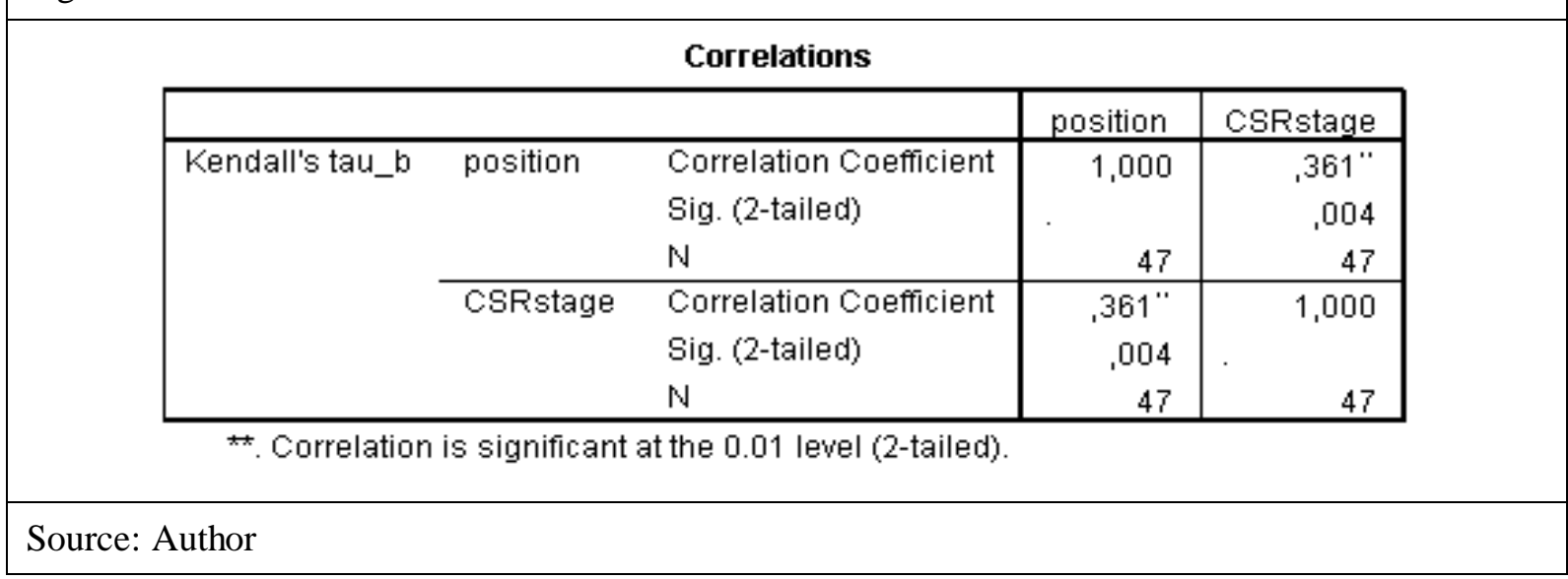

\section{Conclusion}

The concept of corporate social responsibility is adopted on a voluntary basis by organizations in Slovakia. Seemingly, there must be compelling reasons for an organization to adopt socially responsible behavior. Management spends much time and effort to implement corporate socially responsible when motivation for socially responsible behavior is determined by personal conviction of business entity (moral motivation) or outside pressure of conditions or requirements from influential persons or entities (motivation caused by external circumstances). Behavior in accordance with the principles of CSR opens an organization to opportunities that are advantageous both financial and nonfinancial, the importance of which is realized in the long-term functioning of the organization.

\section{Acknowledgement}

This contribution is a partial output of scientific grant VEGA n. 1/0024/15 The Fundamental Research Perception of Corporate Social Responsibility as a Value for Customer.

\section{References}

Bachanova, P., Corejova, T. \& Rostasova, M. (2009). The green issues of postal industry in Europe. 3rd Central European Conference in Regional Science, 901-905.

Caroll, A. B. \& Shabana, K. M. (2010). The Business Case for Corporate Social Responsibility: A Review of Concepts, Research and Practice. International Journal of Management Reviews, 12(1), 85-105. DOI: 10.1111/j.1468-2370.2009.00275 Dytrt, Z. (2006). Dobré jméno firmy [Goodwill]. Praha: Afla Publishing.

Ernst \&Young Global Limited (2013). Survey of the economic benefits and long-term effects of corporate social responsibility on business. Retrieved from http://www.ey.com/LT/en/Home/PR_Survey-of-the-economic-benefits-and-longterm-effects-of-corporate-social-responsibility-on-business

Gregova, E. \& Dengova, E. (2014). Integrated Transport System - A Form of Improving Public Passenger Transport. 2nd International Conference on Social Sciences Research (SSR 2014), Advances in Social and Behavioral Sciences, 5,20 - 25.

Hlaváček, J. \& Hlaváček, M. (2008). Corporate social responsibility (CSR): Proklamace nebo ekonomická nutnost? [Corporate social responsibility (CSR): The proclamation or economic necessity?]. Politická ekonomie [Political Economy], 12(5), 579-597. DOI:10.18267/j.polek.653

Hohnen, P. (2007). Corporate Social Responsibility: An Implementation Guide for Business. Winnipeg: International Institute for Sustainable Development.

Hraskova, D. \& Bartosova, V. (2014). Process based Management in a Profile and Objectives of the Transport Company. 2nd International Conference on Economics and Social Science (ICESS), Advances in Education Research, 61, 109-115.

Kašparová, K. (2009). Důvody angažovanosti v CSR. Vývojové tendence podniků V., Specifický výzkum Katedry podnikového hospodářství [Reasons for involvement in CSR. Development trends of enterprises V. Specific Research of the Department of Corporate Economy]. Brno: Masarykova univerzita [Masaryk University in Brno].

Kuldová, L. (2010). Společenská odpovědnost firrem: Etické podnikání a sociální odpovědnost v praxi [Corporate social responsibility: business ethics and social responsibility in practice]. Kanina: OPS 
Majerova, J. \& Krizanova, A. (2015). Measurement of CSR performance - a necessary condition for effective corporate financial management. 10th International Scientific Conference Financial management of Firms and Financial Institutions. $10,725-732$.

Moravcikova, K., Stefanikova, L. \& Rypakova, M. (2015). CSR reporting as an important tool of CSR communication. Procedia Economics and finance, 26, 332-338. DOI: 10.1016/S2212-5671(15)00861-8

Nadanyiova, M. \& Kramarova, K. (2013). Green marketing and its impacts on consumers' green purchasing behavior. International Scientific Conference on Marketing Identity: Design that Sells. 423-435.

Petříková R., Hofbruckerová Z., Lešingrová R., Klesalová A. \& Hercík P. (2008). Společenská odpovědnost organizací [Corporate social responsibility]. Ostrava: DTO CZ, s.r.o.

Putnová, A. \& Seknička, P. (2007). Etické řízení ve firmě: Nástroje a metody/Etický a sociální audit [Ethical Business Management: Tools and Methods / ethical and social audit]. Praha: Grada.

Putnová, A. (2004). Sociální odpovědnost a etika podnikání [Social responsibility and business ethics]. Brno: CERM.

Rangan, V. K, Chase, L. \& Sohel, K. (2015). The Truth About CSR. Harvard Business Review. Retrieved from https://hbr.org/2015/01/the-truth-about-csr

Srpová, J. \& Kunz, V. (2009). CSR bychom neměli opouštět v době ekonomické krize [CSR should not abandon during the economic crisis]. Ekonomika a manažment [Economics and Management], 3(1), 64-73.

Stefanikova, L., Moravcikova, K. \& Nadanyiova, M. (2015). Corporate Social Responsibility as a Source of Competitive Advantage in Enterprises of the Slovak Republic. 3rd International Conference on Economics and Social Science (ICESS 2015) Advances in Education Research. 86, 168-173.

Tokarcikova, E., Bartosova, V., Kucharcikova, A. \& Durisova, M. (2014). Automotive Company's Social Responsibility in Slovakia. 4th International-Business-Information-Management-Association Conference. I-IV, 2118-2127.

Trnková, J. (2004) Společenská odpovědnost firem - kompletní průvodce tématem \& závěry z průzkumu ČR [Corporate Social Responsibility - the Complete Guide to the theme \& the findings of a survey of the Czech Republic]. Praha: Business Leaders Forum.

Trnková, J. (2006). Rovné priležitosti jako součást společenské odpovednosti firem [Equal opportunities as part of corporate social responsibility]. Praha: Gender Studies.

Veber, J. (2006). Management kvality, environmentu a bezpečnosti práce: Legislativa/Systémy/ Metody/ Praxe [Management of quality, environment and safety at work: Legislation / Systems / Methods / Practice]. Praha: Management Press.

Visser, W. (2010). The Ages and Stages of CSR: From Defensive to Systemic Corporate Sustainability and Responsibility, CSR International Inspiration Series. 8, 1-2. 